\title{
Selective synthesis of $\alpha$-organylthio esters and $\alpha$-organylthio ketones from $\beta$-keto esters and sodium S-organyl sulfurothioates under basic conditions
}

\author{
Jean C. Kazmierczak ${ }^{1}$, Roberta Cargnelutti ${ }^{\ddagger 1}$, Thiago Barcellos ${ }^{\ddagger 2}$, Claudio C. Silveira ${ }^{\ddagger 1}$ \\ and Ricardo F. Schumacher ${ }^{*} 1$
}

\section{Full Research Paper}

\section{Address:}

${ }^{1}$ Departamento de Química, CCNE, Universidade Federal de Santa Maria-UFSM, Santa Maria, 97105-900, RS, Brazil and ${ }^{2}$ Instituto de Biotecnologia Universidade de Caxias do Sul-UCS, Caxias do Sul, RS, Brazil

\section{Email:}

Ricardo F. Schumacher ${ }^{*}$ - ricardo.schumacher@ufsm.br

* Corresponding author $\ddagger$ Equal contributors

Keywords:

$\alpha$-alkylthio esters; $\alpha$-alkylthio ketones; Bunte salts; $\mathrm{C}-\mathrm{C}$ bond

cleavage; $\beta$-keto esters

\author{
Beilstein J. Org. Chem. 2021, 17, 234-244. \\ https://doi.org/10.3762/bjoc.17.24 \\ Received: 10 November 2020 \\ Accepted: 07 January 2021 \\ Published: 26 January 2021 \\ Associate Editor: D. Y.-K. Chen \\ (C) 2021 Kazmierczak et al.; licensee Beilstein-Institut. \\ License and terms: see end of document.
}

\begin{abstract}
We described herein a selective method to prepare $\alpha$-organylthio esters and $\alpha$-organylthio ketones by the reaction of $\beta$-keto esters with sodium $S$-benzyl sulfurothioate or sodium $S$-alkyl sulfurothioate (Bunte salts) under basic conditions in toluene as the solvent at $100{ }^{\circ} \mathrm{C}$. When 4 equivalents of a base were used, a series of differently substituted $\alpha$-thio esters were obtained with up to $90 \%$ yield. On the other hand, employing 2 equivalents of a base, $\alpha$-thio ketones were achieved after $18 \mathrm{~h}$ under air. Furthermore, after a shorter reaction time, the isolation of keto-enol tautomers was possible, revealing them as significant intermediates for the mechanism elucidation.
\end{abstract}

\section{Introduction}

During the last ten years, sodium $S$-organyl sulfurothioates, also known as Bunte salts, were rediscovered by many researchers as stable, nonhygroscopic, and moisture-resistant thiolating agents. Therefore, they have been actively studied as precursors for the preparation of diverse sulfur-containing compounds [1]. These recent findings include their use in direct sulfenylation reactions of electron-rich $N$-heterocycles [2-4], decarboxylative cross-coupling reactions with propiolic acid derivatives
[5], Michael addition reaction [6], cross-couplings catalyzed by $\mathrm{Pd}[7]$ and $\mathrm{Cu}$ salts [8,9], the preparation of symmetrical and nonsymmetrical disulfides [10,11], and the synthesis of $\beta$-acetamido sulfides by the acetamidosulfenylation of alkenes [12], among others [13-15].

Sulfur-containing compounds are important intermediates in organic synthesis, being able to act as an electrophile or nucleo- 
phile in many organic transformations [16-18]. Still, many of them are pharmacologically active as antibiotic, analgesic, antiinflammatory, antidepressant, and antidiabetic agents [19-22].

In this regard, special attention can be given to $\alpha$-thiocarbonyl compounds, which have appeared as synthons in many organic transformations [23-31] and as a core present in several worldwide-consumed drugs and agrochemicals [32-38]. Figure 1 shows examples of these pharmacologically active compounds, such as the antibiotics retapamulin and cefmetazole [32-35], the anticancer agent RETRA [36], and agrochemicals with pesticidal (malathion) and herbicidal applications (fluthiacet-methyl) $[37,38]$.

In this sense, the development of efficient methodologies for the synthesis of sulfur-containing carbonyl compounds employing cheap, stable, nontoxic, easy-to-prepare, and easy-to-handle starting materials is crucial in contemporary organic synthesis and medicinal chemistry. In the last years, different methods have been developed to prepare these classes of molecules, which includes the reaction of alkynes [39-43] as well as $\alpha$-halogenated [44,45] and $\alpha$-diazo carbonyl compounds [46-49] with thiols, diorganyl disulfides, and related compounds. Some of them are catalyzed by expensive transition metals, such as gold, iridium, palladium, and titanium. More recently, the selective formation of $\mathrm{C}-\mathrm{S}$ bonds using 1,3-dicarbonyl compounds, followed by a $\mathrm{C}-\mathrm{C}$ bond cleavage has emerged as a versatile and less expensive protocol to prepare $\alpha$-thiocarbonyl compounds. In this way, Bolm and collaborators elaborated a copper(II) acetate-catalyzed reaction of $\beta$-dicarbonyl compounds with diaryl disulfides (Scheme 1A) [50]. In 2017, Zou and co-workers described the preparation of $\alpha$-thiocarbonyl compounds through a reaction of 1,3-dicarbonyl substrates with diaryl disulfides promoted by $\mathrm{Cs}_{2} \mathrm{CO}_{3}$ at $130{ }^{\circ} \mathrm{C}$ (Scheme 1B) [51]. A year later, Wang and co-workers demonstrated that $\beta$-dicarbonyl compounds could react with thiols at room temperature under an oxygen atmosphere in the presence of a base. This work also demonstrated an easy access to $\alpha$-sulfenylated amides (Scheme 1C) [52].

Inspired by those elegant pioneering studies, we explored the reaction of 1,3-dicarbonyl compounds with Bunte salts mediated by a base (Scheme 1D). The choice of $\mathrm{NaOH}$ as the base and its concentration were crucial to the selective synthesis of $\alpha$-thio esters or $\alpha$-thio ketones starting from $\beta$-keto esters. It is worthwhile to note herein that although some excellent synthetic protocols have already been developed, there is a gap to be filled in the preparation of $\alpha$-benzyl thiocarbonyl and $\alpha$-alkyl thiocarbonyl compounds not fully explored by these recent methods. Thus, the main features of the current strategy include the use of Bunte salts, avoiding air-sensitive and foul-smelling starting materials $[53,54]$ to react with $\beta$-keto esters under $\mathrm{NaOH}$-mediation to selectively produce $\alpha$-thio esters or $\alpha$-thio ketones as target products. Additionally, no prefunctionalization of the carbonyl compounds was required.

\section{Results and Discussion}

We started the investigation of the optimal conditions by varying the amount of the reagents and selecting the ideal base and solvent. For that, we chose ethyl acetoacetate (1a) and sodium $S$-benzyl sulfurothioate (2a) as the standard starting materials to establish the best reaction conditions under an air atmosphere (Table 1).

In our preliminary experiment, a mixture of $\mathbf{1 a}(1.0 \mathrm{mmol})$ and 2a $(0.5 \mathrm{mmol})$, using $\mathrm{NaOH}$ (2 equiv) as a base in toluene

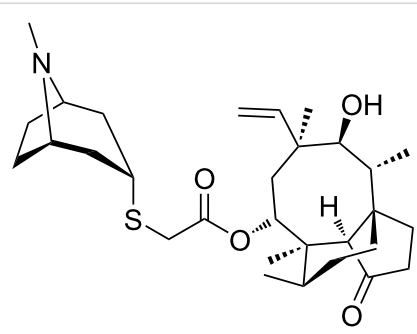

retapamulin<smiles>O=C(CSC1=NCCS1)c1ccc(O)c(O)c1</smiles>

RETRA<smiles>CO[C@]1(NC(=O)CSCC#N)C(=O)N2C(C(=O)O)=C(CSc3nnnn3C)CS[C@H]21</smiles>

cefmetazole<smiles>CCOC(=O)CC(SP(=S)(OC)OC)C(=O)OCC</smiles>

malathion<smiles>COC(=O)CSc1cc(N=c2sc(=O)n3n2CCCC3)c(F)cc1Cl</smiles>

fluthiacet-methyl

Figure 1: Drugs and agrochemicals containing the $\alpha$-thiocarbonyl core as a structural motif. 
previous works

A) Bolm (2013) [50]

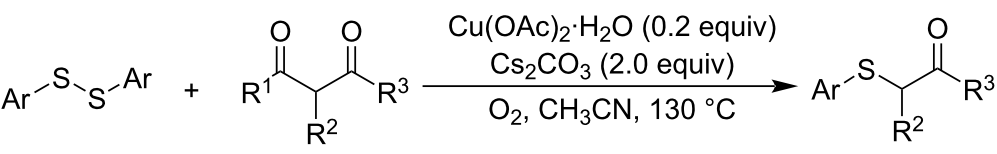

B) Zhang (2017) [51]

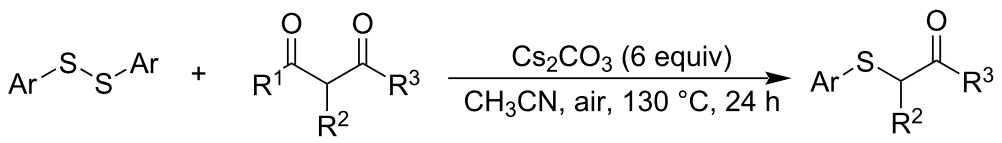

C) Wang (2018) [52]

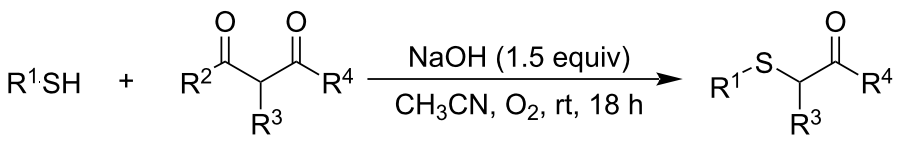

D) this work

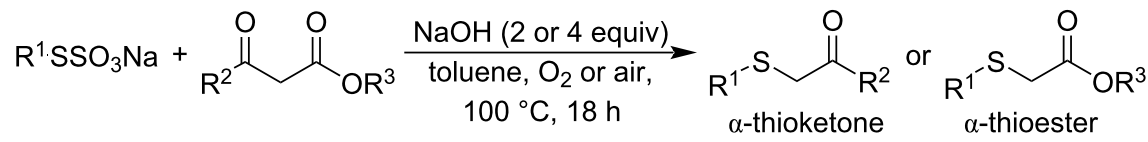

Scheme 1: Methods for the synthesis of $\alpha$-thiocarbonyl compounds by C-C bond cleavage of 1,3-dicarbonyl compounds.

Table 1: Optimization of the reaction conditions. ${ }^{a}$

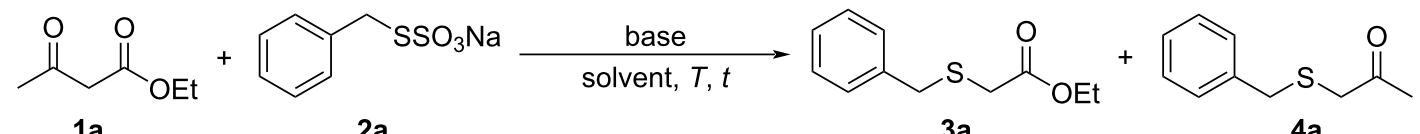

$1 a$

1a, mmol

1.0

1.0

1.0

1.0

1.0

1.0

1.0

1.0

1.0

1.0

1.0

1.0

1.0

1.0

1.0

1.0

1.0

1.0

1.0

0.5

0.5
$2 a$

$$
\text { 2a, mmol }
$$

base, equiv

$\mathrm{NaOH}(2)$

$\mathrm{KOH}(2)$

$\mathrm{K}_{3} \mathrm{PO}_{4}(2)$

$\mathrm{K}_{2} \mathrm{CO}_{3}$ (2)

$\mathrm{Et}_{3} \mathrm{~N}(2)$

DBU (2)

$\mathrm{Cs}_{2} \mathrm{CO}_{3}(2)$

$\mathrm{Na}_{2} \mathrm{CO}_{3}(2)$

$\mathrm{KF}(2)$

$\mathrm{NaOH}(1)$

$\mathrm{NaOH}(4)$

$\mathrm{NaOH}(4)$

$\mathrm{NaOH}(4)$

$\mathrm{NaOH}(4)$

$\mathrm{NaOH}(4)$

$\mathrm{NaOH}(4)$

$\mathrm{NaOH}(4)$

$\mathrm{NaOH}(4)$

$\mathrm{NaOH}(4)$

$\mathrm{NaOH}(4)$

$\mathrm{NaOH}(4)$
$3 a$

yield of $\mathbf{4 a}, \%$

yield of $\mathbf{3 a}, \%$

21

solvent

\section{toluene}

toluene

toluene

toluene

toluene

toluene

toluene

toluene

toluene

toluene

toluene

MeCN

dioxane

DMF

DMSO

THF

DCM

$\mathrm{EtOH}$

acetone

toluene

toluene
44

27

21

31

$-$

$-$

$-$

$-$

$-$

21

traces

20

$-$

$-$

$-$

$-$

traces

$-$

23

40 
Table 1: Optimization of the reaction conditions. ${ }^{a}$ (continued)

\begin{tabular}{|c|c|c|c|c|c|c|}
\hline 22 & 0.5 & 1.0 & $\mathrm{NaOH}(4)$ & toluene $^{c}$ & 86 & - \\
\hline 23 & 0.5 & 1.0 & $\mathrm{NaOH}(2)$ & toluene & 11 & 68 \\
\hline 24 & 0.5 & 1.0 & $\mathrm{NaOH}(2)$ & toluene $^{c}$ & 17 & 42 \\
\hline 25 & 0.5 & 1.0 & $\mathrm{NaOH}(2)$ & toluene $^{d}$ & 47 & 37 \\
\hline 26 & 0.5 & 1.0 & $\mathrm{NaOH}(4)$ & toluene $^{d}$ & 55 & 34 \\
\hline 27 & 0.5 & 1.0 & - & toluene & - & - \\
\hline
\end{tabular}

aThe reactions were conducted using ethyl acetoacetate (1a), sodium $S$-benzyl sulfurothioate $(\mathbf{2 a})$, base, and solvent $(3 \mathrm{~mL})$ at $100{ }^{\circ} \mathrm{C}$ under air for $18 \mathrm{~h}$. ${ }^{\mathrm{b}}$ Reaction conducted at reflux temperature. ${ }^{\mathrm{C}}$ Reaction conducted under an $\mathrm{O}_{2}$ atmosphere. ${ }^{\mathrm{d}}$ Reaction conducted under an $\mathrm{N}_{2}$ atmosphere.

(3.0 mL), was stirred at $100{ }^{\circ} \mathrm{C}$ for $18 \mathrm{~h}$. Under these reaction conditions, the products ethyl 2-(benzylthio)acetate (3a, 20\% yield) and 1-(benzylthio)propan-2-one (4a, 44\% yield) were obtained in a pure form by column chromatography (Table 1 , entry 1). Interestingly, the formation of both an $\alpha$-thio ester and an $\alpha$-thio ketone, starting from ethyl acetoacetate and a sulfur source, was not reported by the previous literature shown in Scheme 1. As such, intrigued by this result and aiming to find selective methods to prepare both $\alpha$-thio carbonyl compounds (3a and 4a), we decided to verify the influence of different inorganic and organic bases on the reaction (Table 1, entries 2-9). During these experiments, neither increments on the reaction yield nor on the selectivity with respect to the obtained the carbonyl compounds were observed. Next, we decided to evaluate the amount of $\mathrm{NaOH}$ by decreasing the amount of base to 1 equiv as well as increasing it to 4 equiv (Table 1, entries 10 and 11). A close inspection showed that 4 equiv of $\mathrm{NaOH}$ increased the amount of ethyl 2-(benzylthio)acetate (3a) to $48 \%$ and only traces of the product $\mathbf{4 a}$ were observed. This result demonstrated the first insight into the selective formation of the carbonyl compound 3a based on the amount of base. With this result in hand and considering 4 equivalents of $\mathrm{NaOH}$ as ideal for the formation of $\mathbf{3 a}$, we then explored the influence of diverse solvents (Table 1, entries 12-19). It can be observed that none of the tested solvents affected the reaction positively. In general, it was observed that polar and protic solvents gave a lower yield when compared to nonpolar and aprotic ones. Keeping toluene as the best solvent, we turned our attention to the amount of 1a and 2a (Table 1, entries 20 and 21). When the mixture of $1 \mathbf{a}(0.5 \mathrm{mmol})$ and $2 \mathrm{a}(1.0 \mathrm{mmol})$ reacted in the presence of $\mathrm{NaOH}$ (4 equiv), the product 3a was obtained in $50 \%$ yield, along with $\mathbf{4 a}$ in a yield of $23 \%$ (Table 1, entry 20 ). When the amount of $S$-benzyl sulfurothioate (2a) was increased to 3 equiv, we found an almost complete consumption of 1a, however, lowering the selectivity of the reaction (Table 1, entry 21). In light of the previous results by Bolm et al. [45] and Wang et al. [47], we turned to conduct the reaction under an oxygen atmosphere (Table 1, entry 22). To our delight, the product 3a was obtained selectively in $86 \%$ yield. In this case, even GC-MS analysis of the crude sample did not show the pres- ence of 4a. With the best conditions to obtain ethyl 2-(benzylthio)acetate (3a) selectively and in a high yield in hand (Table 1, entry 22), we turned our attention to find an ideal protocol to synthesize 4a. When $0.5 \mathrm{mmol}$ of $\mathbf{1 a}$ and $1 \mathrm{mmol}$ of 2a were used in the presence of 2 equivalents of $\mathrm{NaOH}$ under air, compound $4 \mathbf{a}$ was obtained in $68 \%$ yield (Table 1 , entry $23)$. In this case, $11 \%$ of $\mathbf{3 a}$ was also isolated. We considered Table 1, entry 23 as the best conditions to produce 1-(benzylthio)propan-2-one (4a). Lastly, the oxygen or nitrogen atmosphere was prejudice to the formation of $\mathbf{4 a}$, and in the absence of base, no product was obtained (Table 1, entries 24-27). At a lower temperature or at a shorter reaction time, the consumption of the starting materials and the decarboxylation process were incomplete.

Having established the ideal reaction conditions, we first proceeded to examine the reaction of the different $\beta$-keto esters $\mathbf{1 a}-\mathbf{i}$ with the sodium $S$-organyl sulfurothioates $\mathbf{2 a}-\mathbf{j}$ to produce a series $\mathbf{3 a}-\mathbf{r}$ of $\alpha$-organylthio esters (Table 2). Initially, we focused on exploring diverse sodium $S$-benzyl sulfurothioates bearing neutral, electron-donating, and electron-withdrawing substituents in the ortho-, meta-, and para-positions. All reactions occurred smoothly, and the expected $\alpha$-thio esters were obtained in moderate to excellent yield. A close inspection showed that in general, benzyl groups bearing electron-withdrawing groups (i.e., in $\mathbf{2 b - e )}$ gave a lower yield when compared to neutral (i.e., in 2a) and the electron-donating substituents (i.e., in $\mathbf{2 f}-\mathbf{i}$, Table 2, entries 1-9). These results also suggest that the reaction is not sensitive to steric effects since no consistent results were obtained comparing the ortho- and para-substituted benzyl groups (see entries 2 vs 3 and 7 vs 8 in Table 2). Beyond benzyl groups, the sodium $S$-butyl sulfurothioate $\mathbf{2} \mathbf{j}$ was also found to be a suitable reagent for this methodology, providing the corresponding ethyl 2-(butylthio)acetate (3j) in $40 \%$ yield (Table 2 , entry 10 ).

We next surveyed a range of differently substituted $\beta$-keto esters in the reaction with sodium $S$-benzyl sulfurothioate (2a, Table 2, entries 11-18). This protocol enabled the synthesis of various $\alpha$-benzylthio esters $3 \mathbf{k}-\mathbf{r}$ bearing alkyl, allyl, and benzyl 
Table 2: Substrate scope for the synthesis of the $\alpha$-organylthio esters 3 . $^{\text {a }}$

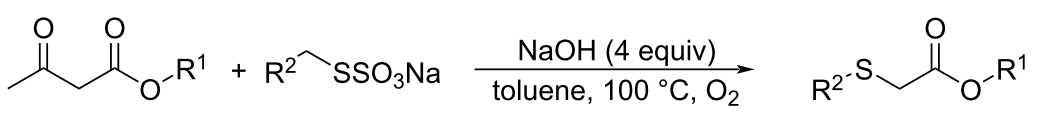

1

2

3

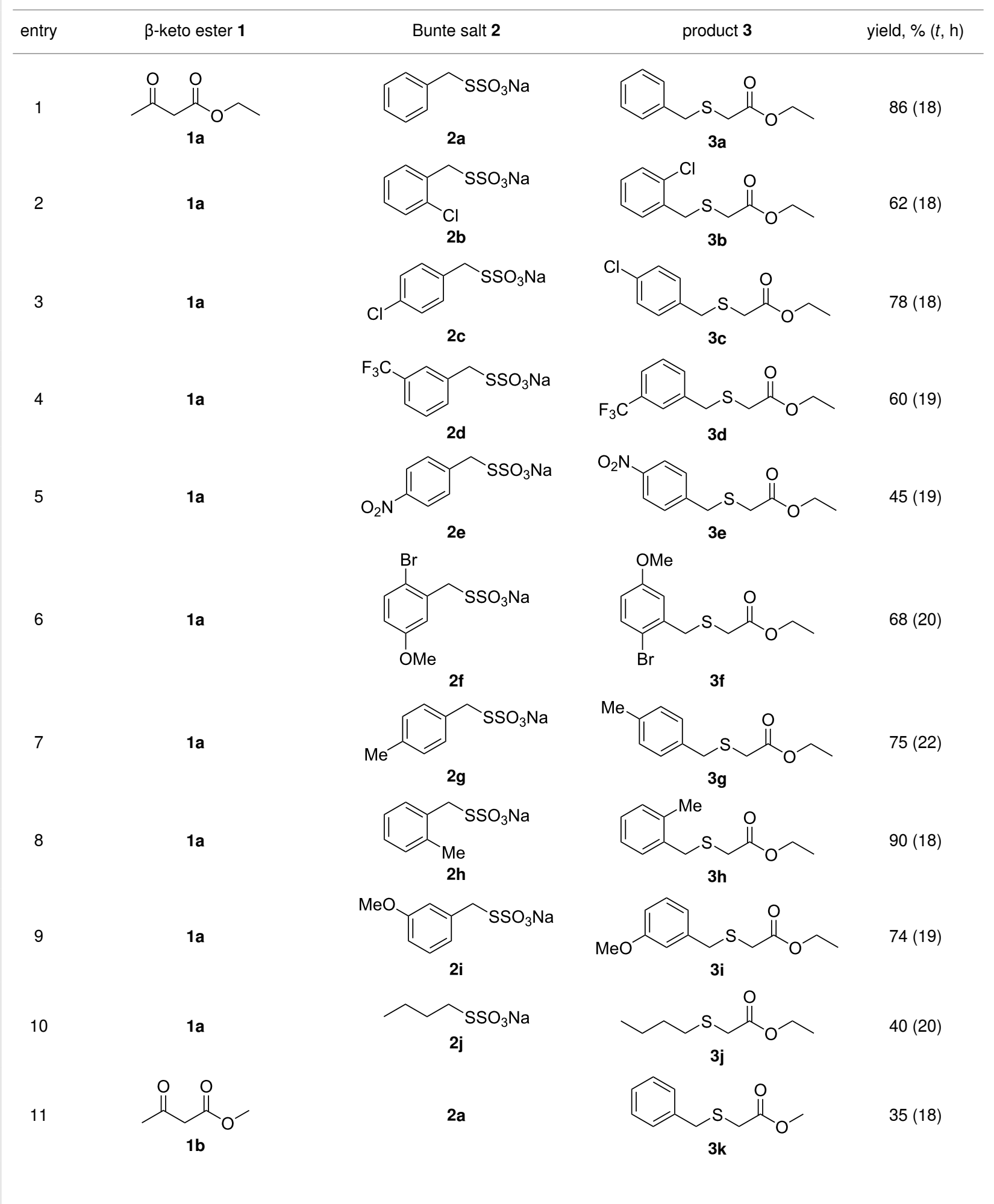


Table 2: Substrate scope for the synthesis of the $\alpha$-organylthio esters $3 .^{\text {a }}$ (continued) $^{-}$

12<smiles>CC(=O)CC(=O)O[13CH3]</smiles>

$1 c$

13<smiles>CC(=O)CC(=O)OC1CCCCC1</smiles>

1d

14<smiles>CC(=O)CC(=O)OC(C)(C)C</smiles>

15<smiles>C=CCOC(=O)CC(C)=O</smiles>

16<smiles>C#CCOC(=O)CC(C)=O</smiles>

$1 \mathrm{~g}$

17<smiles>CC(=O)CC(=O)OCc1ccccc1</smiles>

$1 \mathrm{~h}$

18<smiles>CC(=O)CC(=O)OCCCl</smiles>

$1 i$

19<smiles>CCOC(=O)C(CC)C(C)=O</smiles>

$1 j$
$2 a$<smiles></smiles>

3I

$2 a$<smiles>O=C(CSCc1ccccc1)OC1CCCCC1</smiles>

$3 \mathrm{~m}$

$2 a$<smiles>CC(C)(C)OC(=O)CSCc1ccccc1</smiles>

$3 n$<smiles>C=CCOC(=O)CSCc1ccccc1</smiles>

30<smiles>C#CCOC(=O)CSCc1ccccc1</smiles>

$3 p$<smiles>O=C(CSCc1ccccc1)OCc1ccccc1</smiles>

44 (20)

$3 q$<smiles>O=C(CSCc1ccccc1)OCCCl</smiles>
traces (19)

$3 r$<smiles>CCOC(=O)C(CC)SCc1ccccc1</smiles>

3s

aThe reactions were conducted using a $\beta$-keto ester $1(0.5 \mathrm{mmol})$, a sodium $S$-organyl sulfurothioate $2(1.0 \mathrm{mmol}), \mathrm{NaOH}(4 \mathrm{equiv})$, and toluene

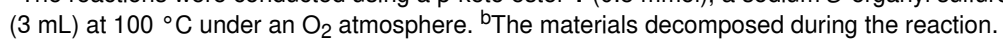

groups directly bonded to the oxygen atom of the ester group. It can be noted that these products were obtained in moderate to good yields. When methyl, octyl, and cyclohexyl 3-oxobutanoates 1b-d reacted with sodium $S$-benzyl sulfurothioate (2a), the expected products $\mathbf{3} \mathbf{k}-\mathbf{m}$ were obtained in only moderate yields (Table 2, entries 11-13). On the other hand, the reaction conducted using the tertiary-alkyl-substituted 3-oxobutanoate (1e) gave tert-butyl 2-(benzylthio)acetate (3n) in 70\% yield (Table 2, entry 14). We also noted that the hybridization of the adjacent carbon atom bonded to the ester group had a direct effect on the formation of the product 3. For instance, comparing entry 1 with entries 15 and 16 in Table 2 , we observed a sudden decrease in the reaction yield, which, we believe, is related to the stability of the starting materials and the formed products in the reaction media. Furthermore, a benzyl group directly bonded to the ester $\mathbf{1 h}$ was also employed under the standard reaction conditions, and after $20 \mathrm{~h}$, benzyl 2-(benzylthio)acetate (3q) was isolated in $44 \%$ yield (Table 2, entry 17). When chloro-substituted ethyl acetoacetate $\mathbf{1 i}$ was used to react with $\mathbf{2 a}$, only traces of the product $\mathbf{3 r}$ were detected (Table 2, entry 18). Finally, limitations were observed also for ethyl 2-ethyl-3-oxobutanoate $(\mathbf{1 j})$, which failed to give the product $3 \mathbf{s}$ (Table 2, entry 19).

Subsequently, we faced the challenge of forming the $\alpha$-organylthio ketones 4 in a base-controlled selective reaction (Table 3). Under the standard reaction conditions (Table 1, entry 22), the products $\mathbf{4 a}-\mathbf{g}$ were obtained in moderate to good 
Table 3: Substrate scope for the synthesis of the $\beta$-organylthio ketones $4 .^{a}$

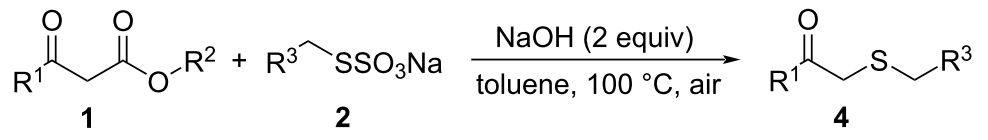

\begin{tabular}{lllll}
\hline entry & $\beta$-keto ester 1 & Bunte salt 2 & product 4 & yield, \% $(t, \mathrm{~h})$ \\
\hline
\end{tabular}

1<smiles>CCOC(=O)CC(C)=O</smiles>

$1 \mathbf{a}$

2

3

5 $1 \mathbf{a}$<smiles>COC(=O)CC(C)=O</smiles>

$1 b$

7<smiles>[Y]C(CC(=O)CCl)OCC</smiles>

8<smiles>CCOC(=O)CC(=O)c1ccccc1</smiles>

11

9<smiles>CCOC(=O)CC(=O)c1ccc(Br)cc1F</smiles>

$1 \mathrm{~m}$<smiles>CCOC(=O)C(CC)C(C)=O</smiles>

1j<smiles>O=S(=O)(O)Cc1ccccc1</smiles>

$2 a$<smiles>O=S(=O)(O)OS(=O)(=O)c1ccccc1Cl</smiles>

$2 b$<smiles>O=S(=O)(Cc1ccc(Cl)cc1)O[Na]</smiles>

2c<smiles>O=S(=O)(O[Na])OCc1cccc(C(F)(F)F)c1</smiles>

2d<smiles>Cc1ccccc1CS(=O)(=O)O[Na]</smiles>

$2 h$<smiles>CC(=O)CSCc1ccccc1</smiles>

$4 a$<smiles>CC(=O)CSCc1ccccc1Cl</smiles>

$4 b$

4c<smiles>CC(=O)CSCc1cccc(C(F)(F)F)c1</smiles>

4d<smiles>CC(=O)CSCc1ccccc1C</smiles>

$4 \mathrm{e}$<smiles>CC(=O)CSCc1ccc(Cl)cc1</smiles>

68 (18)

84 (18)

45 (20)

70 (18)

70 (18)

80 (18)<smiles>O=C(CCl)CSCc1ccccc1</smiles>

traces (20)<smiles>O=C(CSCc1ccccc1)c1ccccc1</smiles>

50 (20)<smiles>O=C(CSCc1ccccc1)c1ccc(Br)cc1F</smiles>

4h

$2 a$<smiles>CCC(SCc1ccccc1)C(C)=O</smiles>

$4 i$

aThe reactions were conducted using a $\beta$-keto ester $1(0.5 \mathrm{mmol})$, a sodium $S$-organyl sulfurothioate $2(1.0 \mathrm{mmol}), \mathrm{NaOH}(2 \mathrm{equiv})$, and toluene $(3 \mathrm{~mL})$ at $100^{\circ} \mathrm{C}$ under air.

yield after chromatographic purification. When we performed the reactions with differently substituted sodium $S$-benzyl sulfurothioates, the products $\mathbf{4 a - e}$ were obtained in yields ranging from $45 \%$ to $84 \%$ (Table 3 , entries $1-5$ ). We also tested methyl acetoacetate (1b) as a starting material to produce 1-(benzylthio)propan-2-one (4a). Interestingly, by this reaction, 
the product $4 \mathbf{a}$ was produced in $80 \%$ yield. This suggests that methyl acetoacetate (1b) is also an appropriate substrate to produce the $\alpha$-thio ketones 4 . Then, we turned our attention to the use of ethyl 4-chloro-3-oxobutanoate (1k) as a starting material to produce 1-(benzylthio)-3-chloropropan-2-one (4f). Unfortunately, after conducting this reaction, only trace amounts of $\mathbf{4 f}$ were obtained, and decomposition of the carbonyl compounds was observed. Thereafter, we explored the potential of the methodology for the ethyl 3-oxo-3-arylpropanoates 11 and $\mathbf{1 m}$. When substrate $\mathbf{1 l}$, containing an unsubstituted phenyl ring, was used, product $\mathbf{4 g}$ was obtained in $50 \%$ yield after $20 \mathrm{~h}$ (Table 3, entry 8). On the other hand, the reaction conducted with halo-substituted substrate $\mathbf{1 m}$ did not give the expected product, and the dicarbonylated starting material was recovered untouched. The reaction mixtures were chromatographed on silica gel, eluting with hexanes/EtOAc 99:1 to isolate the product $\mathbf{4}$ after combining the appropriate fractions. Minor fractions of the corresponding compound 3 were isolated in $6 \%$ to $17 \%$ yield.

In addition, we employed acetylacetone (5) as a reagent to obtain an $\alpha$-thio ketone (Scheme 2). However, when compound 5 reacted with sodium $S$-benzyl sulfurothioate (2a), the enol product 6 was obtained in $86 \%$ yield after $2 \mathrm{~h}$ at $100{ }^{\circ} \mathrm{C}$. In this case even a longer reaction time and a higher temperature were not effective to achieve the $\mathrm{C}-\mathrm{C}$ bond cleavage.

This interesting result also gave us the opportunity to study the formation of keto-enol tautomers, starting from the $\beta$-keto esters 1a and $\mathbf{1 b}$. Then, conducting the reactions using 2 equiv of $\mathrm{NaOH}$ and toluene as the solvent at $100{ }^{\circ} \mathrm{C}$ for only 30 minutes, the products $\mathbf{7}$ and $\mathbf{8}$ were obtained in $70 \%$ and $53 \%$ yield, respectively (Scheme 3 ). The ratio between the keto and the enol tautomer is given based on the ${ }^{1} \mathrm{H}$ NMR analysis. These results are consistent with the report by Tan and collaborators [55] and are evidence to help understand the reaction mechanism.

Although detailed mechanisms for these reactions remain to be elucidated, the literature has clearly demonstrated that many transformations involving $\beta$-keto esters are dependent on the strength and concentration of the base [56-64]. Therefore, based on the above results and on the information from the literature, we propose the following mechanism for the synthesis of $\mathbf{3}$ (Scheme 4) [56-60] and 4 (Scheme 5) [61-64]: We believe that initially, an acidic hydrogen atom bonded to the methylene group between the two carbonyl groups in the $\beta$-keto ester $\mathbf{1}$ is removed by a $\mathrm{HO}^{-}$anion to generate the stabilized carbanion intermediate A. The carbanion then attacks the most available sulfur atom of the sodium $S$-organyl sulfurothioate 2 to produce the keto-enol tautomers B, C, and D. Subsequently, when 4 equiv of $\mathrm{NaOH}$ (concentrated solution) are used, the most electron-deficient carbonyl group experiences a quick attack by the $\mathrm{HO}^{-}$anion, generating the unstable tetrahedral intermediate ion $\mathbf{E}$, the breakdown of which leads to a negatively charged 2-organylthioacetate stabilized by both a carbonyl group and the sulfur atom. Finally, a proton abstraction from the reaction medium produces the target product 3 . We showed that oxygen<smiles>CC(=O)CC(C)=O</smiles>

Scheme 2: Formation of the enol 6 from acetylacetone (5).<smiles>CCOC(=O)CC(C)=O</smiles>

$1 \mathrm{a}$<smiles>COC(=O)CC(C)=O</smiles>

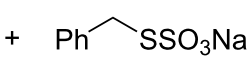
$1 \mathrm{~b}$

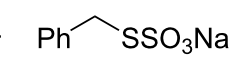
$2 a$ $\underset{\text { toluene, } 100^{\circ} \mathrm{C}}{\stackrel{\mathrm{NaOH}(2 \text { equiv })}{\longrightarrow}}$ $0.5 \mathrm{~h}$, air<smiles>CCOC(=O)/C(SCc1ccccc1)=C(\C)O</smiles><smiles>C1#CCCCC1</smiles>

$7(70 \%)$<smiles>COC(=O)/C(SCc1ccccc1)=C(/C)O</smiles><smiles>C1#CCC1</smiles>

8 (53\%)

$3: 1$<smiles>CCOC(=O)C(SCc1ccccc1)C(C)=O</smiles>
$0.5 \mathrm{~h}$, air<smiles>COC(=O)C(SCc1ccccc1)C(C)=O</smiles> 


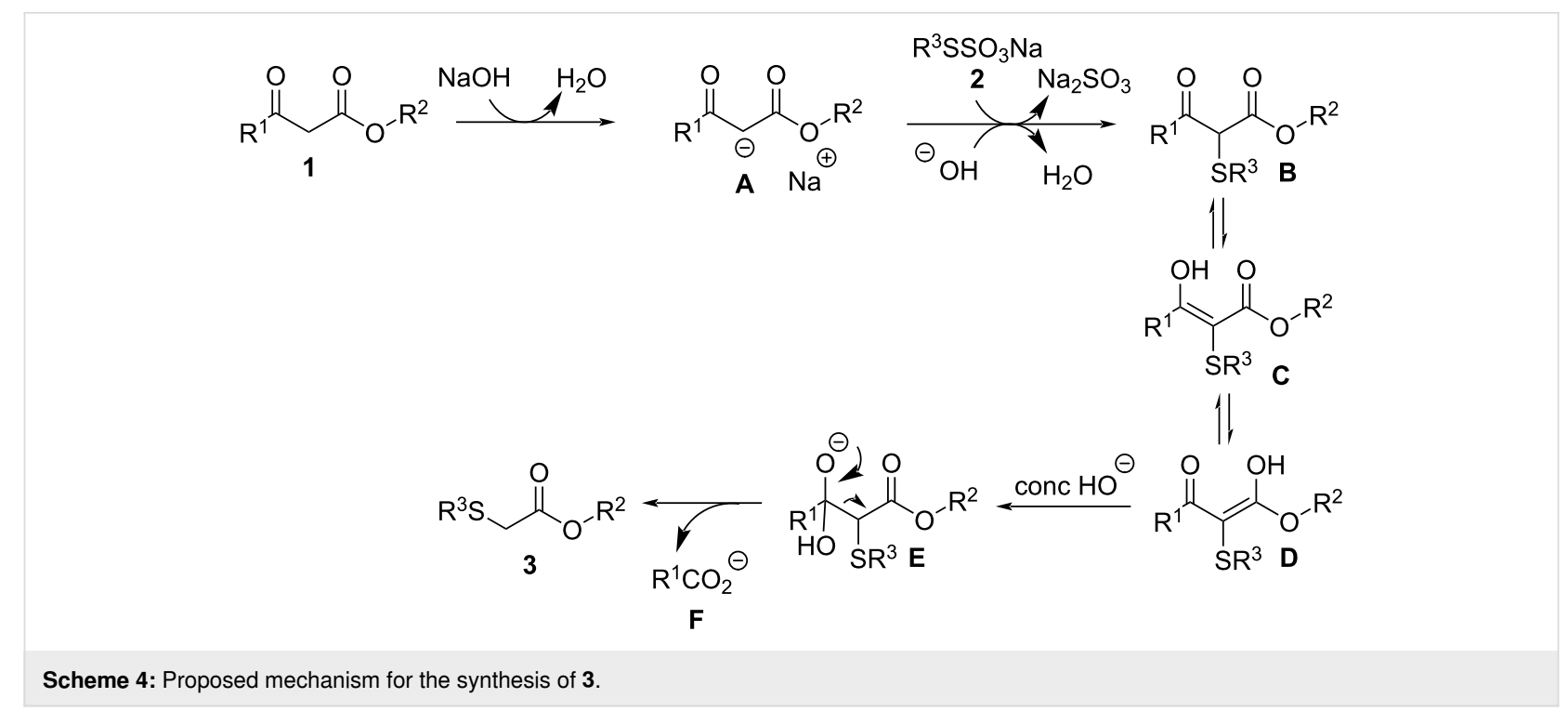<smiles>[R]OC(=O)/C([R3])=C(/[R])O</smiles>

C C dilute $\mathrm{HO}^{\ominus}$ - $\mathrm{R}^{2} \mathrm{OH}$<smiles>[R]OC(O)=C([R])C([R])=O</smiles>

D

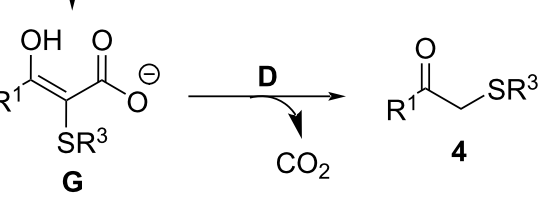

Scheme 5: A tentative pathway for the synthesis of 4

plays an important role in the selective formation of $\mathbf{3}$, but the exact operation of $\mathrm{O}_{2}$ during this process remains unclear at this stage.

A tentative pathway for the formation of compound $\mathbf{4}$ is proposed in Scheme 5. It is well documented that with a dilute amount of base, ester hydrolysis followed by saponification takes place in $\beta$-keto esters, which is followed by $\mathrm{CO}_{2}$ displacement under heating [61-64]. We assume that in our case, when only 2 equiv of base are used, the keto-enol tautomer intermediates undergo a hydrolysis-decarboxylation process preferentially to a retro-Claisen reaction. This process forms the 3-oxocarboxylate ion $\mathbf{G}$, which decarboxylates at a high temperature, providing the product 4 .

Finally, to validate the role of the Bunte salt as a sulfur source and to gain further insights into the mechanisms, several control experiments were performed, as can be seen in Supporting Information File 1.

\section{Conclusion}

In conclusion, we developed simple, efficient, and selective methods for the synthesis of $\alpha$-thio esters and $\alpha$-thio ketones through $\mathrm{NaOH}$-mediated $\mathrm{C}-\mathrm{S}$ bond formation, followed by $\mathrm{C}-\mathrm{C}$ bond cleavage. A broad range of $\beta$-keto esters and sodium $S$-organyl sulfurothioates were used as starting materials. Under the optimized reaction conditions, $\beta$-keto esters were shown to be multifaceted reagents suitable to produce $\alpha$-thio esters or $\alpha$-thio ketones, with the amount of base controlling the selective $\mathrm{C}-\mathrm{C}$ bond cleavage. Sodium $S$-organyl sulfurothioates were satisfactorily used as a sulfur source that is free of unpleasant odor and not air-sensitive. The products were obtained in yields ranging from moderate to excellent. Keto-enol tautomers were isolated and identified as possible reaction inter- 
mediates. All obtained products were fully characterized by NMR and HRMS techniques. Although oxygen plays an important part in the selectivity, the exact role of $\mathrm{O}_{2}$ is currently not clear.

\section{Experimental}

See Supporting Information File 1 for full experimental data of compounds 3,4 , and $6-8$.

\section{Supporting Information}

\section{Supporting Information File 1}

Experimental procedures, characterization data, control experiments, and copies of the ${ }^{1} \mathrm{H},{ }^{13} \mathrm{C}$, and ${ }^{19} \mathrm{~F}$ NMR spectra.

[https://www.beilstein-journals.org/bjoc/content/ supplementary/1860-5397-17-24-S1.pdf]

\section{Funding}

We are grateful to Fundação de Amparo à Pesquisa do Estado do Rio Grande do Sul-Brazil (FAPERGS, PqG 19/25510001947-5) and Conselho Nacional de Desenvolvimento Científico e Tecnológico-Brazil (CNPq) for the financial support and for the fellowship to J. C. K. and C. C. S. This study was financed in part by the Coordenação de Aperfeiçoamento de Pessoal de Nível Superior-Brazil (CAPES)-Finance Code 001.

\section{ORCID ${ }^{\circledR} \mathrm{iDs}$}

Roberta Cargnelutti - https://orcid.org/0000-0002-6865-310X Thiago Barcellos - https://orcid.org/0000-0001-9872-4602 Claudio C. Silveira - https://orcid.org/0000-0002-1918-0000 Ricardo F. Schumacher - https://orcid.org/0000-0003-4723-1925

\section{References}

1. Wang, M.; Li, Y.; Jiang, X. Aldrichimica Acta 2020, 53, 19-25.

2. Ding, Y.; Xie, P.; Zhu, W.; Xu, B.; Zhao, W.; Zhou, A. RSC Adv. 2016, 6, 81932-81935. doi:10.1039/c6ra18136h

3. Li, J.; Cai, Z.-J.; Wang, S.-Y.; Ji, S.-J. Org. Biomol. Chem. 2016, 14, 9384-9387. doi:10.1039/c6ob01528j

4. Qi, H.; Zhang, T.; Wan, K.; Luo, M. J. Org. Chem. 2016, 81, 4262-4268. doi:10.1021/acs.joc.6b00636

5. Liu, F.; Yi, W. Org. Chem. Front. 2018, 5, 428-433. doi:10.1039/c7qo00724h

6. Lin, Y.-m.; Lu, G.-p.; Cai, C.; Yi, W.-b. RSC Adv. 2015, 5, 27107-27111. doi:10.1039/c5ra01381j

7. Qiao, Z.; Wei, J.; Jiang, X. Org. Lett. 2014, 16, 1212-1215. doi:10.1021/ol500112y

8. Qiao, Z.; Ge, N.; Jiang, X. Chem. Commun. 2015, 51, 10295-10298. doi:10.1039/c5cc03038b
9. Li, Y.; Pu, J.; Jiang, X. Org. Lett. 2014, 16, 2692-2695. doi:10.1021/ol5009747

10. Abbasi, M.; Mohammadizadeh, M. R.; Saeedi, N. New J. Chem. 2016, 40, 89-92. doi:10.1039/c5nj01885d

11. Xiao, X.; Feng, M.; Jiang, X. Chem. Commun. 2015, 51, 4208-4211. doi:10.1039/c4cc09633a

12. Zhang, R.; Yan, Z.; Wang, D.; Wang, Y.; Lin, S. Synlett 2017, 28 1195-1200. doi:10.1055/s-0036-1588144

13. Li, G.; Zhang, G.; Deng, X.; Qu, K.; Wang, H.; Wei, W.; Yang, D. Org. Biomol. Chem. 2018, 16, 8015-8019. doi:10.1039/c8ob02268b

14. Liao, Y.-S.; Liang, C.-F. Org. Biomol. Chem. 2018, 16, 1871-1881. doi:10.1039/c8ob00178b

15. Qiao, M.; Zhang, J.; Chen, L.; Zhou, F.; Zhang, Y.; Zhou, L.; Wu, Y. Org. Biomol. Chem. 2019, 17, 3790-3796. doi:10.1039/c9ob00336c

16. Raghavan, S.; Chiluveru, R. K.; Subramanian, S. G. J. Org. Chem. 2016, 81, 4252-4261. doi:10.1021/acs.joc.6b00616

17. Beletskaya, I. P.; Ananikov, V. P. Chem. Rev. 2011, 111, 1596-1636. doi:10.1021/cr100347k

18. Koval', I. V. Russ. Chem. Rev. 1994, 63, 147-168. doi:10.1070/rc1994v063n02abeh000077

19. Takenoshita, S.; Nishino, S. J. Sleep Med. Clin. 2020, 15, 177-194. doi:10.1016/j.jsmc.2020.02.006

20. Lücking, U. Org. Chem. Front. 2019, 6, 1319-1324. doi:10.1039/c8qo01233d

21. Feng, M.; Tang, B.; Liang, S. H.; Jiang, X. Curr. Top. Med. Chem. 2016, 16, 1200-1216. doi:10.2174/1568026615666150915111741

22. Ilardi, E. A.; Vitaku, E.; Njardarson, J. T. J. Med. Chem. 2014, 57, 2832-2842. doi:10.1021/jm401375q

23. Gao, W.-C.; Zhao, J.-J.; Hu, F.; Chang, H.-H.; Li, X.; Wei, W.-L. RSC Adv. 2015, 5, 25222-25228. doi:10.1039/c5ra03826j

24. Pan, X.-J.; Gao, J.; Yuan, G.-Q. Tetrahedron 2015, 71, 5525-5530. doi:10.1016/j.tet.2015.06.063

25. Mulina, O. M.; Pirgach, D. A.; Nikishin, G. I.; Terent'ev, A. O. Eur. J. Org. Chem. 2019, 4179-4188. doi:10.1002/ejoc.201900258

26. Gao, W.-C.; Tian, J.; Shang, Y.-Z.; Jiang, X. Chem. Sci. 2020, 11, 3903-3908. doi:10.1039/d0sc01060j

27. Xu, X.-B.; Lin, Z.-H.; Liu, Y.; Guo, J.; He, Y. Org. Biomol. Chem. 2017, 15, 2716-2720. doi:10.1039/c7ob00277g

28. Kwak, S. H.; Lim, S.-J.; Yoo, H.-J.; Ha, J.-E.; Gong, Y.-D. Synthesis 2016, 48, 4131-4142. doi:10.1055/s-0035-1562613

29. Sunaga, T.; Atobe, M.; Inagi, S.; Fuchigami, T. Chem. Commun. 2009, 956-958. doi:10.1039/b817860g

30. John, J. P.; Novikov, A. V. Org. Lett. 2007, 9, 61-63. doi:10.1021/ol062592h

31. Basato, M.; Cardinale, A.; Salvò, S.; Tubaro, C.; Benetollo, F. Inorg. Chim. Acta 2005, 358, 659-666. doi:10.1016/j.ica.2004.10.014

32. Li, Y.-G.; Wang, J.-X.; Zhang, G.-N.; Zhu, M.; You, X.-F.; Hu, X.-X.; Zhang, F.; Wang, Y.-C. Chem. Biodiversity 2019, 16, e1800560. doi:10.1002/cbdv.201800560

33. Mundy, L. M.; Sampson, T.; Logie, J. W. Pediatr. Drugs 2014, 16, 331-336. doi:10.1007/s40272-014-0077-1

34. Shang, R.; Pu, X.; Xu, X.; Xin, Z.; Zhang, C.; Guo, W.; Liu, Y.; Liang, J. J. Med. Chem. 2014, 57, 5664-5678. doi:10.1021/jm500374c

35. Schentag, J. J. Pharmacotherapy 1991, 11, 2-19.

36. Sonnemann, J.; Grauel, D.; Blümel, L.; Hentschel, J.; Marx, C.; Blumrich, A.; Focke, K.; Becker, S.; Wittig, S.; Schinkel, S.; Krämer, O. H.; Beck, J. F. Eur. J. Cancer 2015, 51, 841-851. doi:10.1016/j.ejca.2015.02.016 
37. Lamberth, C.; Walter, H.; Kessabi, F. M.; Quaranta, L.; Beaudegnies, R.; Trah, S.; Jeanguenat, A.; Cederbaum, F. Phosphorus, Sulfur Silicon Relat. Elem. 2015, 190, 1225-1235. doi:10.1080/10426507.2014.984033

38. Jeschke, P. Pest Manage. Sci. 2016, 72, 210-225. doi:10.1002/ps.4170

39. Lv, Y.; Liu, Q.; Liu, F.; Yue, H.; Li, J.-S.; Wei, W. Tetrahedron Lett. 2020, 61, 151335. doi:10.1016/j.tetlet.2019.151335

40. Margalef, J.; Watile, R. A.; Rukkijakan, T.; Samec, J. S. M. J. Org. Chem. 2019, 84, 11219-11227. doi:10.1021/acs.joc.9b01424

41. Zhang, Z.; Luo, Y.; Du, H.; Xu, J.; Li, P. Chem. Sci. 2019, 10, 5156-5161. doi:10.1039/c9sc00568d

42. Li, J.; Ji, K.; Zheng, R.; Nelson, J.; Zhang, L. Chem. Commun. 2014, 50, 4130-4133. doi:10.1039/c4cc00739e

43. Lu, Q.; Zhang, J.; Zhao, G.; Qi, Y.; Wang, H.; Lei, A. J. Am. Chem. Soc. 2013, 135, 11481-11484. doi:10.1021/ja4052685

44. Heredia, A. A.; López-Vidal, M. G.; Kurina-Sanz, M.; Bisogno, F. R.; Peñéñory, A. B. Beilstein J. Org. Chem. 2019, 15, 378-387. doi:10.3762/bjoc. 15.34

45. Ranu, B. C.; Jana, R. Adv. Synth. Catal. 2005, 347, 1811-1818. doi:10.1002/adsc.200505122

46. Zhang, Y.-Z.; Zhu, S.-F.; Cai, Y.; Mao, H.-X.; Zhou, Q.-L. Chem. Commun. 2009, 5362-5364. doi:10.1039/b911670b

47. Hock, K. J.; Koenigs, R. M. Angew. Chem., Int. Ed. 2017, 56, 13566-13568. doi:10.1002/anie.201707092

48. Chan, K.-H.; Guan, X.; Lo, V. K.-Y.; Che, C.-M. Angew. Chem., Int. Ed. 2014, 53, 2982-2987. doi:10.1002/anie.201309888

49. Dairo, T. O.; Woo, L. K. Organometallics 2017, 36, 927-934. doi:10.1021/acs.organomet.6b00947

50. Zou, L.-H.; Priebbenow, D. L.; Wang, L.; Mottweiler, J.; Bolm, C. Adv. Synth. Catal. 2013, 355, 2558-2563. doi:10.1002/adsc.201300566

51. Zou, L.-H.; Zhao, C.; Li, P.-G.; Wang, Y.; Li, J. J. Org. Chem. 2017, 82, 12892-12898. doi:10.1021/acs.joc.7b02384

52. Jiang, Y.; Deng, J.-d.; Wang, H.-h.; Zou, J.-x.; Wang, Y.-q.; Chen, J.-h.; Zhu, L.-q.; Zhang, H.-h.; Peng, X.; Wang, Z. Chem. Commun. 2018, 54, 802-805. doi:10.1039/c7cc09026a

53. Qiao, Z.; Jiang, X. Org. Biomol. Chem. 2017, 15, 1942-1946. doi:10.1039/c6ob02833k

54. Node, M.; Kumar, K.; Nishide, K.; Ohsugi, S.-i.; Miyamoto, T. Tetrahedron Lett. 2001, 42, 9207-9210. doi:10.1016/s0040-4039(01)02024-x

55. Tan, J.; Liang, F.; Wang, Y.; Cheng, X.; Liu, Q.; Yuan, H. Org. Lett. 2008, 10, 2485-2488. doi:10.1021/ol800765s

56. He, C.; Guo, S.; Huang, L.; Lei, A. J. Am. Chem. Soc. 2010, 132, 8273-8275. doi:10.1021/ja1033777

57. Zeevaart, J. G.; Parkinson, C. J.; de Koning, C. B. Tetrahedron Lett. 2007, 48, 3289-3293. doi:10.1016/j.tetlet.2007.02.136

58. Zsolczai, D.; Németh, J.; Hell, Z. Tetrahedron Lett. 2015, 56, 6389-6392. doi:10.1016/j.tetlet.2015.09.136

59. Katritzky, A. R.; Wang, Z.; Wang, M.; Wilkerson, C. R.; Hall, C. D.; Akhmedov, N. G. J. Org. Chem. 2004, 69, 6617-6622. doi:10.1021/jo049274l

60. Yang, D.; Zhou, Y.; Xue, N.; Qu, J. J. Org. Chem. 2013, 78, 4171-4176. doi:10.1021/jo400280p

61. Wang, Z. In Comprehensive Organic Name Reactions and Reagents; Wang, D. Z., Ed.; John Wiley \& Sons, 2010; pp 9-12. doi:10.1002/9780470638859

62. Asaoka, M.; Miyake, K.; Takei, H. Bull. Chem. Soc. Jpn. 1978, 51 , 3008-3010. doi:10.1246/bcsj.51.3008
63. Renfrow, W. B.; Walker, G. B. J. Am. Chem. Soc. 1948, 70, 3957-3958. doi:10.1021/ja01191a529

64. Connor, R.; Adkins, H. J. Am. Chem. Soc. 1932, 54, 3420-3427. doi:10.1021/ja01347a065

\section{License and Terms}

This is an Open Access article under the terms of the Creative Commons Attribution License (https://creativecommons.org/licenses/by/4.0). Please note that the reuse, redistribution and reproduction in particular requires that the author(s) and source are credited and that individual graphics may be subject to special legal provisions.

The license is subject to the Beilstein Journal of Organic Chemistry terms and conditions:

(https://www.beilstein-journals.org/bjoc/terms)

The definitive version of this article is the electronic one which can be found at: https://doi.org/10.3762/bjoc.17.24 